\title{
Molecular Methods of Studying Microbial Diversity in Soil Environments
}

\author{
Liu Zhao ${ }^{1,2}$, Zhihong Ma ${ }^{1,2}$, Yunxia Luan ${ }^{1,2}$, Anxiang Lu ${ }^{1,2}$, \\ Jihua Wang ${ }^{1,2}$, and Ligang $\operatorname{Pan}^{1,2, *}$ \\ ${ }^{1}$ Beijing Research Center for Agrifood Testing and Farmland Monitoring, \\ 100097 Beijing, China \\ ${ }^{2}$ Beijing Research Center for Information Technology in Agriculture, 100097 Beijing, China \\ Tel.: +8610 51503031; Fax: +861051503406 \\ zhaoliu@nercita.org.cn, panlg@nercita.org.cn
}

\begin{abstract}
Microorganisms live in all parts of the biosphere and are critical to nutrient recycling in ecosystems. In recent years, the development of methodologies for the analysis of microorganisms and microbial ecology, at the molecular level, has progressed phenomenally. This review introduces and compares the various molecular methods for studying microbial diversity in soil environments, and the advantages and disadvantages of current methods are proposed as well.
\end{abstract}

Keywords: Microbial diversity; SIP; T-RFLP; RAPD; DGGE; Soil.

\section{Introduction}

Microorganisms are ubiquitous in the environment and fulfill a range of important ecological functions, particularly those associated with nutrients cycling processes and maintenance of ecosystem health in soil ${ }^{[1]}$. Soil contain an estimated 109 prokaryotes and more than 2000 genome types per gram of soil, with an average genome type representing less than $0.05 \%$ of the soil community ${ }^{[2-3]}$.

Until a few decades ago, soil microorganisms could only be studied by microscopic observation or culture-dependent methods. In less than a decade, using nucleic acid probe technique for the detection of microorganisms had exploded. Nowadays, molecular ecology techniques based on sequence comparisons of nucleic acids can be used to provide molecular characterization while providing a classification scheme that predicts natural evolutionary relationships ${ }^{[4-5]}$.

These laboratory-based works have been spectacularly successful in revealing details of soil microbial diversity. So we attempt to draw together some of these studies, with emphasis on the advantages and disadvantages of current molecular methods, for studying microbial diversity in soil environments.

\footnotetext{
* Corresponding author.
} 


\section{Stable Isotope Probing}

Stable isotope probing (SIP) has been coupled with nucleic acid methods to provide a culture-independent method of linking the identity of bacteria with their function in the environment ${ }^{[6-7]}$. Soil is either incubated after adding a ${ }^{13} \mathrm{C}$-labeled substrate or a plant is labeled with ${ }^{13} \mathrm{C}-\mathrm{CO}_{2}$. Soil DNA or RNA is then extracted and centrifuged in a density gradient to separate ${ }^{13} \mathrm{C}$-labeled nucleic acids from those containing. Then separated, labeled DNA can be amplified using PCR. Analysis of the PCR products, through cloning and sequencing for example, allows the microbes that have assimilated the labeled substrate to be identified ${ }^{[8-9]}$. SIP-based approaches hold great potential for linking microbial identity with function, but at present a high degree of labeling is necessary to be able to separate labeled from unlabeled marker molecules.

\section{Terminal-Restriction Fragment Length Polymorphism}

Terminal-restriction fragment length polymorphism (T-RFLP) has multiple advantages for its rapid gain in popularity: data are quantitative and comparable between laboratories, the final electrophoresis step can be performed with automated sequencing equipment at core sequencing facilities ${ }^{[10]}$. This method provides a picture of the community including incorporates diversity and phylogenetic details. The profiles can be generated by using the procedure from physical-capture ${ }^{[11]}$, fluorescence scanner ${ }^{[12]}$ or ${ }^{32}$ P-labelled primers ${ }^{[13]}$. Because of its relative simplicity, T-RFLP has been applied to the analysis of soil microbial diversity, for instance, fungal ribosomal genes ${ }^{[14-15]}$, bacterial 16S rRNA genes ${ }^{[16-17]}$, and archaeal $16 \mathrm{~S}$ rRNA genes ${ }^{[18]}$. In addition, TRFLP has been used for the analysis of functional genes such as those encoding for nitrogen fixation and methane oxidation ${ }^{[19-20]}$.

\section{Fluorescence in Situ Hybridization}

Fluorescence in situ hybridization (FISH) is a relatively new technique utilizing fluorescently labeled DNA probe to detect genes of microorganisms in soil samples. Apart from allowing direct visualization of bacteria in the environment, FISH also has the added advantage of being able to detect active cells by targeting rRNA. This method has been reliably used for identification and quantification of ammoniaoxidizing bacteria ${ }^{[21-22]}$. Several studies have used FISH coupled with microautoradiography (FISH-MAR), this combined approach allows in situ identification and provides information on substrate utilization in complex microbial communities ${ }^{[23-24]}$.

\section{Microarray}

Microarray for microbial community analysis has been classified into three main categories depending on the combination of probe types and target molecules exploited: community genome arrays, rRNA-based oligonucleotide microarrays and functional gene arrays ${ }^{[25-26]}$. Tiquia constructed a 50-mer oligonucleotide microarray 
using 763 genes involved in nitrogen cycling ${ }^{[27]}$. The increased use of cultivationindependent metagenomic approaches employing large-insert cloning could lead to an important extension of the CGA approach for large genomic fragments from uncultivated microorganisms ${ }^{[28-29]}$. In the meantime, adapting enzymatic signal amplification approaches for microarray analysis ${ }^{[30-31]}$, the use of high sensitivity microarray hybridization detection devices hold much promise for enhancing the sensitivity of direct detection of extracted rRNA ${ }^{[32-34]}$.

\section{Random Amplified Polymorphic DNA}

Random amplified polymorphic DNA (RAPD) use DNA products by PCR which are based on random priming of the target DNA, these primers are usually 10 bases in length and are designed to a number of random target sites ${ }^{[35]}$. Huai studied the genetic variation and spatial distribution of the ectomycorrhizal fungus, the 33 sporophores studied belonged to distinct genotypes ${ }^{[36]}$. The advantage of this approach is that it requires very little sample material and obtains results rapidly. However, this method is less susceptible to base changes in the target DNA. Thus usually the PCR is performed at low stringency for the first few cycles. This technique allows the generation of product when mismatches between template and primers occur. Hence, similar patterns generated using this technique better reflect phylogeny of the phages. One disadvantage of this technology is the results may be difficult to repeat by other users $^{[37-38]}$.

\section{DNA Fingerprinting}

DNA fingerprinting is used to distinguish differences in the genetic makeup of microbial populations from different samples. The advantage of this technique is that it enable high sample throughput and can be used to target sequences that are phylogenetically or functionally significant. Nowadays, the most common used techniques are denaturing gradient gel electrophoresis (DGGE) or temperature gradient gel electrophoresis (TGGE). They have been used to profile fungal microbial communities from many diverse environments ${ }^{[39-40]}$. DGGE fingerprints of total DNA from rhizosphere revealed that there was a relationship between fungal community composition and rhizosphere development ${ }^{[41]}$. Fungal community diversity was studied by PCR-DGGE followed by sequence analyses of ITS fragments in soil samples ${ }^{[42]}$. Although DGGE is a promising technique, it can still underestimate fungal diversity. The number of bands depends on the resolution of the gels, this takes time to optimize and is difficult to reproduce ${ }^{[43]}$. This has already been demonstrated in previous studies that phylogenetically distant taxa can have comigrating bands and that one band does not mean one unique phylotype ${ }^{[44-45]}$.

A new DNA-based fingerprinting approach, two-dimensional polyacrylamide gel electrophoresis (2D-PAGE), can be used to separate PCR amplicon of the ITS regions ${ }^{[46]}$. But this technique does not lend itself to high sample throughput. However, its improved ability to discriminate between soil communities and retrieve sequence information make it a powerful technique for elucidating key differences in community structure. 


\section{Conclusions and Future Directions}

Soil has been dubbed "The Final Frontier". Current knowledge pertaining to the diversity and distribution of soil ecosystem is still rudimentary. In recent years, obviously improvement in traditional approaches combined with various molecular techniques, such as molecular and phylogenetic inventorying via clone libraries ${ }^{[47]}$, quantitative real-time $\mathrm{PCR}^{[48]}$, pyrosequencing ${ }^{[49]}$, quantitative membrane hybridization $^{[50]}$ has provided new data on these aspects. Nonetheless, we feel that these sophisticated methods are highly relevant to the existing knowledge of the role of microorganism in ecosystem processes, but the application of the techniques to this end is far from complete.

From recent molecular ecological studies, we have seen that most carbon- and nitrogen- cycling gene sequences are divergent from those of the model organisms on which most of our existing appreciation of biogeochemical cycles are based. However, our understanding of ecologically relevant microorganism involved in these cycles is limited. Hence we are aware that further understanding of how they fit into the complexities of ecosystems will require both bottom-up and top-down approaches.

Acknowledgments. This work was supported by the public foundation from Beijing Municipal Rural Affair Committee (20080901), National High Technology Research and Development Program 863 (2010AA10Z403, 2007AA10Z202) and Beijing Municipal Science and Technology Commission Program (Z09090501040901).

\section{References}

1. Nannipieri, P.: Role of stabilised enzymes in microbial ecology and enzyme extraction from soil with potential applications in soil proteomics. In: Nannipieri, P., Smalla, K. (eds.) Nucleic Acids and Proteins in Soil, pp. 75-94. Springer, Heidelberg (2006)

2. Torsvik, V., Øvreås, L.: Microbial diversity and function in soil: from genes to ecosystems. Curr. Opin. Microbiol. 5, 240-245 (2002)

3. Gans, J., Wolinsky, M., Dunbar, J.: Computational improvements reveal great bacterial diversity and high metal toxicity in soil. Science 309, 1387-1390 (2005)

4. Handelsman, J., Smalla, K.: Conversations with the silent majority. Curr. Opin. Microbiol. 6, 271-273 (2003)

5. Schutte, U.M., Abdo, Z., Bent, S.J., Shyu, C., Williams, C.J., Pierson, J.D., Forney, L.J.: Advances in the use of terminal restriction fragment length polymorphism (T-RFLP) analysis of $16 \mathrm{~S}$ rRNA genes to characterize microbial communities. Appl. Microbiol. Biotechnol. 80(3), 365-380 (2008)

6. McDonald, I.R., Radajewski, S., Murrell, J.C.: Stable isotope probing of nucleic acids in methanotrophs and methylotrophs: a review. Org. Geochem. 36, 779-787 (2005)

7. Dumont, M.G., Murrell, J.C.: Stable isotope probing-linking microbial identity to function. Nat. Rev. Microbiol. 3, 499-504 (2005)

8. Griffiths, R.I., Manefield, M., Bailey, M.J., Whiteley, A.S., Ostle, N., McNamara, N., O'Donnell, A.G.: $\left(\mathrm{CO}_{2}\right)-{ }^{13} \mathrm{C}$ pulse labelling of plants in tandem with stable isotope probing: methodological considerations for examining microbial function in the rhizosphere. $\mathrm{J}$. Microbiol. Methods. 58, 119-129 (2004) 
9. Leake, J.R., Ostle, N.J., Rangel-Castro, J.I., Johnson, D.: Carbon fluxes from plants through soil organisms determined by field $\left(\mathrm{CO}_{2}\right){ }^{13} \mathrm{C}$ pulse-labelling in an upland grassland. Appl. Soil. Ecol. 33, 152-175 (2006)

10. Bent, J., Forney, L.J.: The tragedy of the uncommon: understanding limitations in the analysis of microbial diversity. ISME. J. 2, 689-695 (2008)

11. Blackwood, C.B., Buyer, J.S.: Evaluating the physical-capture method of terminal restriction fragment length polymorphism. Soil. Biol. Biochem. 39(2), 590-599 (2007)

12. Ikeda, S., Roberts, D.M., Watanabe, K.N., Ytow, N.: Microbial community analyses using a simple, rapid detection method for DNA fingerprints with a fluorescence scanner. J. Biosci. Bioeng. 98, 500-503 (2004)

13. Dunfield, K.E., Germida, J.J.: Seasonal changes in the rhizosphere microbial communities associated with field-grown genetically modified canola (Brassicanapus). Appl. Environ. Microbiol. 69, 7310-7318 (2003)

14. Genney, D.R., Anderson, I.C., Alexander, I.J.: Fine-scale distribution of pine ectomycorrhizas and their extramatrical mycelium. New. Phytol. 170, 381-390 (2006)

15. Kennedy, N., Edwards, S., Clipson, N.: Soil bacterial and fungal community structure across a range of unimproved and semi-improved upland grasslands. Microbiol. Ecol. 50, 463-473 (2005)

16. Hullar, M.A.J., Kaplan, L.A., Stahl, D.A.: Recurring seasonal dynamics of microbial communities in stream habits. Appl. Environ. Microbiol. 72, 713-722 (2006)

17. Thies, J.E.: Soil microbial community analysis using terminal restriction fragment length polymorphisms. Soil. Sci. Soc. Am. 71, 579-591 (2007)

18. Leybo, A.I., Netrusov, A.I., Conrad, R.: Effect of hydrogen concentration on the community structure of hydrogenotrophic methanogens studied by T-RFLP analysis of 16S rRNA gene amplicons. Microbiol. 75, 683-688 (2006)

19. Mohanty, S.R., Bodelier, P.L.E., Virgilio, F., Ralf, C.: Differential effects of nitrogenous fertilizers onmethane-consuming microbes in rice field and forest soils. Appl. Environ. Microbiol. 72, 1346-1354 (2006)

20. Zak, D.R., Blackwood, C.B., Waldrop, M.P.: A molecular dawn for biogeochemistry. Trends. Ecol. E 21, 288-295 (2006)

21. Briones, A.M., Okabe, S., Umemiya, Y., Ramsing, N.B., Reichardt, W., Okuyama, H.: Influence of different cultivars on populations of ammonia-oxidizing bacteria in the root environment of rice. Appl. Environ. Microbiol. 68, 3067-3075 (2002)

22. Meyer, R.L., Zeng, R.J., Giugliano, V., Blackall, L.L.: Challenges for simultaneous nitrification, denitrification, and phosphorus removal in microbial aggregates: mass transfer limitation and nitrousoxide production. FEMS. Microbiol. Ecol. 52, 329-338 (2005)

23. Ouverney, C.C., Fuhrman, J.A.: Combined microautoradiography-16S rRNA probe technique for determination of radioisotope uptake by specific microbial cell types in situ. Appl. Environ. Microbiol. 65, 1746-1752 (1999)

24. Zwirglmaier, K.: Fluorescence in situ hybridisation (FISH)-the next generation. FEMS. Microbiol. Lett. 246, 151-158 (2005)

25. Zhou, J., Thompson, D.K.: Challenges in applying microarrays to environmental studies. Curr. Opin. Biotech. 13, 204-207 (2002)

26. Zhou, J.: Microarrays for bacterial detection and microbial community analysis. Curr. Opin. Microbiol. 6, 288-294 (2003)

27. Tiquia, S.M., Wu, L., Chong, S.C., Passovets, S., Xu, D., Xu, Y., Zhou, J.: Evaluation of 50 -mer oligonucleotide arrays for detecting microbial populations in environmental samples. Biotechniques 36, 664-675 (2004) 
28. Handelsman, J.: Metagenomics: application of genomics to uncultured microorganisms. Microbiol. Mol. Biol. Rev. 68, 669-685 (2004)

29. Riesenfeld, C.S., Schloss, P.D., Handelsman, J.: Metagenomics: genomic analysis of microbial communities. Annu. Rev. Genet. 38, 525-552 (2004)

30. Small, J., Call, D.R., Brockman, F.J., Straub, T.M., Chandler, D.P.: Direct detection of 16S rRNA in soil extracts by using oligonucleotide microarrays. Appl. Environ. Microbiol. 67, 4708-4716 (2001)

31. Denef, V.J., Park, J., Rodrigues, J.L.M., Tsoi, T.V., Hashsham, S.A., Tiedje, J.M.: Validation of a more sensitive method for using spotted oligonucleotide DNA microarrays for functional genomics studies on bacterial communities. Environ. Microbiol. 5, 933-943 (2003)

32. McKendry, R., Zhang, J., Arntz, Y., Strunz, T., Hegner, M., Lang, H.P., Baller, M.K., Certa, U., Meyer, E., Guntherodt, H.J., Gerber, C.: Multiple label-free biodetection and quantitative DNA-binding assays on a nanomechanical cantilever array. PNAS 99, 9783 9788 (2002)

33. Epstein, J.R., Leung, A.P.K., Lee, K.H., Walt, D.R.: High-density, microsphere-based fiber optic DNA microarrays. Biosens. Bioelectron. 18, 541-546 (2003)

34. Thompson, M., Cheran, L.E., Zhang, M.Q., Chacko, M., Hong, H., Sadeghi, S.: Label-free detection of nucleic acid and protein microarrays by scanning Kelvin nanoprobe. Biosens. Bioelectron. 20, 1471-1481 (2005)

35. Podila, G.K., Lanfranco, L.: Functional genomic approaches for studies of mycorrhizal symbiosis. In: Podila, G.K., Lanfranco, L. (eds.) Plant Surface Microbiology, pp. 567-592. Springer, Heidelberg (2004)

36. Huai, W.X., Guo, L.D., He, W.: Genetic diversity of an ectomycorrhizal fungus Tricholoma terreum in a Larix principis-rupprechtii stand assessed using random amplified polymorphic DNA. Mycorrhiza 13, 265-270 (2003)

37. Micheli, M.R., Bova, R., Pascale, E., D’Ambrosio, E.: Reproducible DNA fingerprinting with the random amplified polymorphic DNA (RAPD) method. Nucl. Acids. Res. 22, 1921-1922 (1994)

38. Henry, S., Baudoin, E., Lopez-Gutierrez, J.C.: Quantification of denitrifying bacteria in soils by nirK gene targeted real-time PCR. J. Microbiol. Meth. 59, 327-335 (2004)

39. Möhlenhof, P., Müller, L., Gorbushina, A.A., Petersen, K.: Molecular approach to the characterisation of fungal communities: methods for DNA extraction, PCR amplification and DGGE analysis of painted art objects. FEMS. Microbiol. Lett. 195, 169-173 (2001)

40. Nikolcheva, L.G., Cockshutt, A.M., Bärlocher, F.: Determining diversity of fungi on decaying leaves: comparison of traditional and molecular approaches. Appl. Environ. Microbiol. 69, 2548-2554 (2003)

41. Gomes, N.C.M., Fagbola, O., Costa, R., Rumjanek, N.G., Buchner, A., Mendona-Hagler, L., Smalla, K.: Dynamics of fungal communities in bulk and maize rhizosphere soil in the tropics. Appl. Environ. Microbiol. 69, 3758-3766 (2003)

42. Anderson, I.C., Campbell, C.D., Prosser, J.I.: Potential bias of fungal 18S rDNA and internal transcribed spacer polymerase chain reaction primers for estimating fungal biodiversity in soil. Environ. Microbiol. 5, 36-47 (2003)

43. Fromin, N., Hamelin, J., Tarnawski, S., Roesti, D., Jourdain-Miserez, K., Forestier, N., Teyssier-Cuvelle, S., Gillet, F., Aragno, M., Rossi, P.: Statistical analysis of denaturing gel electrophoresis (DGGE) fingerprinting patterns. Environ. Microbiol. 4, 634-643 (2002)

44. Sekiguchi, H., Tomioka, N., Nakahara, T., Uchiyama, H.: A single band does not always represent single bacterial strains in denaturing gradient gel electrophoresis. Biotechnol. Lett. 23, 1205-1208 (2001) 
45. Kisand, V., Wikner, J.: Limited resolution of $16 \mathrm{~S}$ rDNA DGGE caused by melting properties and closely related DNA sequences. J. Microbiol. Meth. 54, 183-191 (2003)

46. Jones, C.M., Thies, J.E.: Soil microbial community analysis using two-dimensional polyacrylamide gel electrophoresis of the bacterial ribosomal internal transcribed spacer regions. J. Microbiol. Meth. 69, 256-267 (2007)

47. Loy, A., Küsel, K., Lehner, A., Drake, H.L., Wagner, M.: Microarray and functional gene analyses of sulfate-reducing prokaryotes in low sulfate, acidic fens reveal co-occurrence of recognized genera and novel lineages. Appl. Environ. Microbiol. 70, 6998-7009 (2004)

48. Kolb, S., Knief, C., Stubner, S., Conrad, R.: Quantitative detection of methanotrophs in soil by novel pmoA-targeted real-time PCR assays. Appl. Environ. Microbiol. 69, 24232429 (2003)

49. Huber, J.A., Mark Welch, D.B., Morrison, H.G., Huse, S.M., Neal, P.R., Butterfield, D.A., Sogin, M.L.: Microbial population structures in the deep marine biosphere. Science 318, 97-100 (2007)

50. Hristova, K.R., Mau, M., Zheng, D., Aminov, R.I., Mackie, R.I., Gaskins, H.R., Raskin, L.: Desulfotomaculum genus- and subgenus-specific 16S rRNA hybridization probes for environmental studies. Environ. Microbiol. 2, 143-159 (2000) 